Article

\title{
Zinc/Silver Particle (Zn/AgP) Composite Coatings: Evaluation of Corrosion in Physiological Environments and Antibacterial Activity against $P$. aeruginosa
}

\author{
Berenice Castro-Rodríguez ${ }^{1}$, Arnulfo Terán-López ${ }^{1}$, Yolanda Reyes-Vidal ${ }^{1}$ (D), \\ Francisco J. Bácame-Valenzuela ${ }^{1}{ }^{\mathbb{D}}$, José G. Flores ${ }^{1}$, Raúl Ortega ${ }^{1}$, José Mojica ${ }^{1}$, \\ Erika Acosta-Smith ${ }^{2}$, Jorge Vázquez-Arenas ${ }^{3}$, René H. Lara ${ }^{4}$ and Gabriel Trejo ${ }^{1, *(D)}$ \\ 1 Centro de Investigación y Desarrollo Tecnológico en Electroquímica (CIDETEQ), Parque Tecnológico \\ Sanfandila, Querétaro C.P. 76703, Mexico; bcastro@cideteq.mx (B.C.-R.); ateran@cideteq.mx (A.T.-L.); \\ mreyes@cideteq.mx (Y.R.-V.); fbacame@cideteq.mx (F.J.B.-V.); jflores@cideteq.mx (J.G.F.); \\ rortega@cideteq.mx (R.O.); jmojica@cideteq.mx (J.M.) \\ 2 Facultad de Medicina, Centro de Investigación en Salud Aplicada (CIASaP), Universidad Autónoma de \\ Sinaloa, Sinaloa C.P. 80246, Mexico; erika.acosta@uas.edu.mx \\ 3 Conacyt-Departamento de Química, Universidad Autónoma Metropolitana-Iztapalapa, Av. San Rafael \\ Atlixco No 186, Mexico City 09340, Mexico; jorge_gva@hotmail.com \\ 4 Laboratorio de Electroquímica y Análisis de Superficies, Facultad de Ciencias Químicas, Departamento de \\ Ciencia de Materiales, Universidad Juárez del Estado de Durango (UJED) Circuito Universitario, \\ Durango 34120, Mexico; Icrh75@hotmail.com \\ * Correspondence: gtrejo@cideteq.mx
}

Received: 21 February 2020; Accepted: 23 March 2020; Published: 1 April 2020

\begin{abstract}
In this work, zinc/silver particle ( $\mathrm{Zn} / \mathrm{AgP})$ composite coatings were manufactured by electrodeposition to investigate their antibacterial capacity and corrosion rate in physiological environments. The morphology and composition of the coatings were analysed by glow-discharge optical emission spectroscopy and scanning electron microscopy coupled to an energy dispersive spectrometer. The results showed the formation of $\mathrm{Zn} / \mathrm{AgP}$ composite coatings with a homogeneous distribution of Ag throughout the coating surface and depth. Additionally, the Ag content in the coatings increased with increasing concentrations of $\mathrm{AgP}$ in the electrolytic solution. The $\mathrm{Zn} / \mathrm{AgP}$ composite coatings with $0.30 \mathrm{wt} . \% \mathrm{Ag}$ on the surface $\left(0.30 \mathrm{wt} . \% \mathrm{Ag}_{\text {surf }}\right)$ showed efficiencies close to $100 \%$ growth inhibition of the bacteria Pseudomonas aeruginosa after $10 \mathrm{~min}$ of contact. The corrosion rate of the $\mathrm{Zn}$ and the $\mathrm{Zn} / \mathrm{AgP}$ ( $0.30 \mathrm{wt} . \% \mathrm{Ag}_{\text {surf }}$ ) coatings in Hank's, Ringer's and Phosphate buffered saline (PBS) solutions was evaluated by polarization curves and by immersion tests over different time periods (7, 30, and 40 days). The corrosion rate of the $\mathrm{Zn} / \mathrm{AgP}$ ( $\left.0.30 \mathrm{wt} . \% \mathrm{Ag}_{\text {surf }}\right)$ coatings was on the order of tenths of microns per year and the amount of zinc mass dissolving per day was in the range of 0.15 to $0.7 \mathrm{mg} \mathrm{cm}^{-2}$. Additionally, the surface of the coatings was analysed by X-ray diffraction (XRD) after 40 days of immersion. These results showed the formation of $\mathrm{ZnO}$, as the main corrosion product, in the samples immersed in Hank's and Ringer's solutions. In the samples immersed in PBS, the formation of a passivating film of $\mathrm{Zn}_{2}\left(\mathrm{PO}_{4}\right)_{3} \cdot 2 \mathrm{H}_{2} \mathrm{O}$ was detected.
\end{abstract}

Keywords: antibacterial coatings; composites coatings; silver nanoparticles; zinc

\section{Introduction}

A current trend in the technological development of materials is the use of biodegradable metals, which have been proposed as an alternative in the manufacturing of temporary implants, that is, 
in implants that should only be used during the time necessary to heal the wound; these metals must subsequently be degraded and bioabsorbed completely to be discarded by the body. Metals such as $\mathrm{Fe}$, $\mathrm{Mn}, \mathrm{Mg}, \mathrm{Zn}$, and $\mathrm{W}$ have been proposed as biodegradable metals [1], with $\mathrm{Mg}$ being the most accepted due to its physical characteristics and biocompatibility. $\mathrm{Mg}$ has a density of $1.74 \mathrm{~g} \mathrm{~cm}^{-3}$, which is very similar to that of human cortical bone $\left(1.75 \mathrm{~g} \mathrm{~cm}^{-3}\right)$, and its Young's modulus (41 to $45 \mathrm{GPa}$ ) is also close to that of human bone (3 to $20 \mathrm{GPs}$ ). Additionally, $\mathrm{Mg}$ participates in many metabolic reactions and is a metal that is present in large amounts in the human body; the daily demand for magnesium is $375 \mathrm{mg}$ [2]. Due to these characteristics, $\mathrm{Mg}$ is an ideal candidate as a biodegradable material for temporary implants, such as cardiovascular stents. Despite the advantages of $\mathrm{Mg}$ as a biodegradable implant, its use has been restricted due to its high corrosion rate $\left(250 \mu \mathrm{m} \mathrm{yr}^{-1}\right)$ in the physiological environment with high concentrations of chloride ions, which cause Mg-based implants to degrade before achieving complete healing [3]. Additionally, the Mg oxidation process produces hydrogen bubbles, and this production slows the healing process.

Several materials have been studied as $\mathrm{Mg}$ substitutes for use in biodegradable implants [2]; these materials have been the main basis for the development of various types of alloys. In this regard, Heublein et al. [4] tested the magnesium alloy AE21 as a coronary stent, observing a rapid degradation of the alloy over a period of 35 to 56 days after implantation. On the other hand, Krause et al. [5] tested the Mg-0.8Ca alloy in vivo, finding that it was very stable because it maintained more than half its volume after implantation in the tibia of rabbit. Mg-6Zn binary alloys were studied by Zhang et al. [6], finding good in vitro biocompatibility and adequate mechanical properties. However, in vivo tests showed that the degradation rate of the alloy was greater than that of $\mathrm{Mg}$. Ternary $\mathrm{Mg}-\mathrm{Zn}-\mathrm{Ca}$ alloys ( $4 \mathrm{wt} . \% \mathrm{Zn}$ ) have been tested, showing excellent mechanical properties and greater resistance to corrosion [7]. However, after 30 days of exposure in simulated body fluid (SBF) solution, their physical properties decreased considerably.

The utility of Fe as a biodegradable material for implants has been proven in different studies [8,9] without finding toxicity problems, inflammations or restenosis. However, its moderate degradation rate limits its biodegradability and therefore its applications as a biodegradable metal. To overcome this limitation, Fe alloys have also been tested as materials for biodegradable implants. Mantovani et al. [10] investigated the degradation of Fe-Mn alloys under flow conditions, simulating those of a coronary artery, obtaining iron hydroxides and calcium/phosphorus layers as degradation products. On the other hand, Schinhammer et al. [11] demonstrated that the degradation rate of the Fe-Mn-C-(-Pd) alloy is greater than that of the Fe-Mn alloy. The main problem in the use of Fe-Mn alloys is the high content of $\mathrm{Mn}$, which ranges from $20 \%$ to $35 \%$, which could cause toxicity problems.

In recent years, zinc [12] and zinc-based alloys have been proposed as alternatives to replace Mg-based alloys because their corrosion rate $\left(\sim 20 \mu \mathrm{m} \cdot \mathrm{yr}^{-1}\right)$ is lower than that of $\mathrm{Mg}$ [13] and because they have high biocompatibility; $\mathrm{Zn}$ is one of the most abundant essential nutritional elements in the human body, and the recommended daily requirement of zinc is between 15 and $100 \mathrm{mg}^{\text {day }}{ }^{-1}$ [14]. Additionally, $\mathrm{Zn}$ is very important in several biological processes, such as in hormonal mediation and DNA and RNA synthesis; it also participates in nearly 300 enzymatic reactions [15]. In this sense, Niu et al. [16] proposed a $\mathrm{Zn}-\mathrm{Cu}$ alloy as a biodegradable material for application in vascular stents. Törne et al. [17] studied the degradation mechanism of $\mathrm{Zn}-\mathrm{Mg}$ and $\mathrm{Zn}-\mathrm{Ag}$ alloys obtained by smelting at $550{ }^{\circ} \mathrm{C}$, immersed in Ringer's solutions. The microgalvanic corrosion of the $\mathrm{Zn}$ - $\mathrm{Ag}$ alloy causes the accumulation of the $\mathrm{AgZn}_{3}$ phase on the surface, and this accumulation could cause complications in the regeneration of the tissue. The $\mathrm{Zn}-\mathrm{Mg}$ alloy selectively dissolves, causing local precipitation of the corrosion products, which increase the corrosion rate. Similarly, Sikora-Jasinska et al. [18] manufactured $\mathrm{Zn}-\mathrm{Ag}$ alloys of different compositions by casting at $650{ }^{\circ} \mathrm{C}$, observing an increase in the corrosion rate when increasing the Ag content in the alloy using Hank's solution as electrolyte. This fact is associated with the greater formation of $\mathrm{AgZn}_{3}$. Additionally, Mostaed et al. [19] studied the corrosion of $\mathrm{Zn}-\mathrm{Mg}$ alloys formed by hot extrusion in modified Hank's solution, observing a loss in the mechanical integrity of the alloy due to the increase of the volume fraction of a second phase during 
the corrosion process, causing local galvanic corrosion pitting. Recently, Hehrlein et al. [20] reported results of in vivo tests using $\mathrm{Zn}$ - $\mathrm{Ag}$ alloy ( $3 \mathrm{wt} . \% \mathrm{Ag}$ ) (obtained by smelting at $650{ }^{\circ} \mathrm{C}$ ) as bioresorbable vascular stents. Their results showed that the degradation of $\mathrm{Zn}-3 \mathrm{Ag}$ stents in porcine iliac arteries occurred without toxicological problems or vascular occlusion and maintained vascular scaffolding for a minimum period of 6 months.

Another option that has been proposed to produce implants with controlled degradation and prolonged mechanical stability is coatings. The coatings are thin films that isolate and protect the substrate from the surrounding environment, maintaining the physical properties of the substrate. One of the main characteristics of the coatings is that they must degrade at a controlled rate so that they will protect the substrate only for a certain time. Various types of biodegradable coatings have been proposed, either organic, such as polylactic acid (PLA) [21], polycaprolactone (PCL) [22] and polypyrrole [23] or inorganics such as calcium phosphates [24] and fluoride [25].

On the other hand, nosocomial infections are one of the most common complications associated with surgical implants. These infections not only cost a large amount of money but also delay the healing time and can even lead to disability and death. It has been shown that bacterial infection is the second most important factor leading to failure in implantation [26]. Therefore, it is important to develop materials with bactericidal capacity that can prevent early infection in the area of the implant.

In this study, we analyzed zinc/silver particle $(\mathrm{Zn} / \mathrm{AgP})$ composite coatings as protective biodegradable coatings with antibacterial capacity for potential use in biomedical applications. The $\mathrm{Zn} / \mathrm{AgP}$ composite coatings were obtained by electrodeposition on American Iron and Steel Institute (AISI) 1018 steel substrates. The bactericidal capacity was evaluated with respect to the bacterium Pseudomonas aeruginosa, as this is one of the main bacteria causing nosocomial infections $[27,28]$. Corrosion of the coatings in different physiological environments-Ringer's, Hank's and PBS solutions-was studied by polarization curves and immersion. The corrosion products were characterized by X-ray diffraction (XRD).

\section{Materials and Methods}

\subsection{Electrodeposition of Zinc/Silver Particle ( $\mathrm{Zn/AgP}$ ) Composites Coatings}

The $\mathrm{Zn} / \mathrm{AgP}$ composite coatings were formed by galvanostatic electrodeposition, applying a current density of $8.5 \mathrm{~mA} \mathrm{~cm}{ }^{-2}$ for $60 \mathrm{~min}$ at $25^{\circ} \mathrm{C}$, using a $\mathrm{S}_{0}$ solution $\left(=81 \mathrm{~g} \cdot \mathrm{L}^{-1} \mathrm{ZnCl}_{2}+25 \mathrm{~g} \cdot \mathrm{L}^{-1}\right.$ $\mathrm{H}_{3} \mathrm{BO}_{3},+208.8 \mathrm{~g} \cdot \mathrm{L}^{-1} \mathrm{KCl}+1.5 \mathrm{~g} \cdot \mathrm{L}^{-1} \mathrm{PEG} 8000+0.2 \mathrm{~g} \cdot \mathrm{L}^{-1} \mathrm{BDA}+0.03 \mathrm{~g} \cdot \mathrm{L}^{-1}$ cetyl trimethylammonium hydrogen sulphate (CTHS) $+2.8 \mathrm{~g} \cdot \mathrm{L}^{-1}$ triethanolamine $)+x \mathrm{~g} \cdot \mathrm{L}^{-1} \mathrm{AgPs}(x=0,0.5,1.5,2.5,3.5$ or 4.5). The average size of the silver particles (AgPs) was $60 \mathrm{~nm}(99.9 \%$, SkySpring Nanomaterials Inc., Houston, TX, USA), the size of the silver particles was selected from additional bacteriological tests (not presented in this work), using silver particles of different sizes: 30, 60, and $100 \mathrm{~nm}$. Each solution was prepared before each experiment using analytical-grade reagents $(99.9 \%$ purity, Sigma Aldrich, St. Louis, MI, USA). A parallel plate cell manufactured in acrylic with a distance of $5 \mathrm{~cm}$ between electrodes was used as the electrochemical cell. As a cathode, AISI 1018 steel plates $\left(8 \mathrm{~cm}^{2}\right.$ of exposed area) were used and were previously degreased and activated. Zn plates ( $99 \%$, Atotech, Feucht, Germany) were used as anodes.

\subsection{Chemical Composition and Morphological Characterization}

The elemental composition profiles as a function of the thickness of the $\mathrm{Zn} / \mathrm{AgP}$ composite coatings were obtained using glow-discharge optical emission spectrometry (GD-OES) (Profilometer 2, Horiba, Kyoto, Japan), setting the following parameters: $650 \mathrm{~Pa}$ and $35 \mathrm{~W}$. The following spectral lines were recorded: $130.21 \mathrm{~nm} \mathrm{O,} 481.05 \mathrm{~nm} \mathrm{Zn}, 328.06 \mathrm{~nm} \mathrm{Ag}, 156.14 \mathrm{~nm} \mathrm{C,} 385.99 \mathrm{~nm}$ Fe, $121.56 \mathrm{~nm}$ $\mathrm{H}$, and $149.26 \mathrm{~nm} \mathrm{~N}$. The morphology and surface composition of the coatings was analyzed by scanning electron microscopy (JEOL JSM-6510 LV, Tokyo, Japan) coupled to an energy-dispersive X-ray spectroscope (SEM-EDX) (Bruker Quantax 200, Berlin, Germany), with an acceleration voltage of $55 \mathrm{kV}$, using SE imaging. Atomic Force Microscopy (AFM) (Asylum Research, Mod. MFP-3D, Santa Barbara, 
CA, USA) in tapping mode was used to obtain images of the $\mathrm{Zn} / \mathrm{AgP}$ composite coatings. All images were obtained at $1.5 \mathrm{~Hz}$.

\subsection{Antibacterial Activity of the $\mathrm{Zn} / \mathrm{AgP}$ Composite Coatings}

The antibacterial activity of the $\mathrm{Zn} / \mathrm{AgP}$ composite coatings was analyzed with respect to Pseudomonas aeruginosa (P. aeruginosa) NEJ01R according to International Standarization Organization (ISO) method 22196, "Measurement of antibacterial activity on plastics and other non-porous surfaces" [29]. This strain was inoculated in Luria Bertani broth (LB) (bacto-tryptone, 10 g; yeast extract, $5 \mathrm{~g} ; \mathrm{NaCl}, 10 \mathrm{~g}$ and deionized water, up to $1000 \mathrm{~mL}$ ) and incubated for $24 \mathrm{~h}$ at $30{ }^{\circ} \mathrm{C}$ and $150 \mathrm{rpm}$. After reaching a cell density of $10^{9} \mathrm{CFU} \mathrm{mL} \mathrm{m}^{-1}$ (CFU: colony forming unit), evaluated from turbidity measurements (15\% transmittance, $650 \mathrm{~nm}$ ), the $\mathrm{Zn} / \mathrm{AgP}$ composites with different $\mathrm{Ag}$ content were placed in the fermentation broth and maintained for contact times of $0.0,5,10,30$, 60 and $1440 \mathrm{~min}$. After this time, cell density was diluted to $10^{8} \mathrm{CFU} \mathrm{mL}^{-1}$ in $0.1 \mathrm{mM}^{-1}$ phosphate buffer $\mathrm{pH}$ 7.0. Petri dishes with LB agar were inoculated with $1 \mathrm{~mL}$ of the $10^{8} \mathrm{CFU} \mathrm{mL} \mathrm{m}^{-1}$ dilution and incubated at $30^{\circ} \mathrm{C}$ for $24 \mathrm{~h}$. After the incubation period, the CFU mL $\mathrm{m}^{-1}$ was determined by counting the number of colonies established on the agar plate using a colony counter (Mod. Galaxy 230, Rocher Scientific, Taipei, Taiwan). As a control, a Zn coating without AgP was used. The quantification was realized as in ASTM E2149-01, "Standard test method for determining the antimicrobial activity of immobilized antimicrobial agents under dynamic contact conditions" [30]. The percentage reduction of the organisms resulting after different contact times $(5,10,30,60$, and $1440 \mathrm{~min}$.) between the $\mathrm{Zn} / \mathrm{AgP}$ composite coatings and the bacterial strain was calculated using reduction percentage $(\%)=((B-A) / B)$ $\times 100$, where $A=\mathrm{CFU}$ per milliliter in the flask containing the treated substrate after the different contact times, $B=$ the number of initial $\mathrm{CFU} \mathrm{mL} \mathrm{mL}^{-1}$ before the addition of the treated substrate.

\subsection{Corrosion Test}

Corrosion tests for polarization curves were performed according to the ASTM G59-97 standard [31] using a conventional three-electrode cell and a Bio-logic SP150 potentiostat/galvanostat. A saturated calomel electrode (SCE) was used as the reference electrode, and a platinum mesh was used as the counter electrode, each placed inside a separate compartment. For this study, Zn or Zn/AgP composite (0.30 wt.\% Ag $\mathrm{Asurf}_{\text {s }}$ ) coatings were prepared on electrodes made of AISI 1018 steel with an exposed geometric area of $1.5 \mathrm{~cm}^{2}$.

The corrosion behavior of the $\mathrm{Zn} / \mathrm{AgP}$ coatings was studied in different solutions: Hank's, Ringer's and PBS (Sigma Aldrich, St. Louis, MI, USA), whose compositions, reported by the manufacturer, are shown in Table 1:

Table 1. Composition of the physiological solutions used in the corrosion tests.

\begin{tabular}{ccccccccc}
\hline \multirow{2}{*}{ Physiological } & $\mathrm{CaCl}_{2} \cdot \mathbf{2} \mathbf{H}_{\mathbf{2}} \mathbf{O}$ & $\mathbf{M g C l}_{2} \cdot \mathbf{6} \mathbf{H}_{\mathbf{2}} \mathbf{O}$ & $\mathbf{K C l}$ & $\mathbf{N a H C O}_{3}$ & $\mathbf{N a C l}$ & $\mathbf{N a H}_{2} \mathbf{P O}_{4}$ & Glucose & $\mathbf{K H}_{2} \mathbf{P O}_{4}$ \\
\hline Hank's & 0.265 & 0.214 & 0.2 & 1 & 8 & 0.05 & 1 & - \\
Ringer's & 0.12 & - & 0.105 & 0.05 & 2.25 & - & - & - \\
PBS & - & - & - & - & - & 17.385 & - & 10.764 \\
\hline
\end{tabular}

\subsection{Immersion Test}

The immersion corrosion tests were performed according to the NACE TMO 169/G31-12a standard [32]. Rectangular plates of AISI 1018 steel coated on both sides with $\mathrm{Zn}$ or $\mathrm{Zn} / \mathrm{AgP}$ composite ( $0.30 \mathrm{wt} . \% \mathrm{Ag}_{\text {surf }}$ ) were immersed in sterilized glass containers with $200 \mathrm{~mL}$ of saline solution (Hank's, Ringer's or PBS). The immersed area of each sample was $8 \mathrm{~cm}^{2}(1.0 \mathrm{~cm} \times 4 \mathrm{~cm}$ per face). The temperature was maintained at $37^{\circ} \mathrm{C}$ with a recirculating bath, $\mathrm{pH}=7.0$. The samples of $\mathrm{Zn}$ and $\mathrm{Zn} / \mathrm{AgP}(0.30 \mathrm{wt} . \%$ $\mathrm{Ag}_{\text {surf }}$ immersed in each of the solutions were removed and analyzed after different test times: 7, 22, and 40 days. After the immersion corrosion tests, the surface morphology was analyzed by SEM-EDX, and the formed phases were analyzed by XRD using a Bruker diffractometer (model D8 Advance) in 
Bragg-Brentano configuration, with a $\mathrm{Cu} K \alpha$ radiation source $(\lambda=1.54 \AA)$ and scanning from $30^{\circ}$ to $150^{\circ}$ of $2 \theta^{\circ}$ with a scan rate of $0.2^{\circ} \mathrm{s}^{-1}$.

\section{Results}

\subsection{Chemical Composition and Morphology of Zn/AgP Composite Coatings}

The influence of the concentration of silver particles $(\mathrm{AgP})$ in the electrolytic solution on the morphology and elemental composition of the $\mathrm{Zn} / \mathrm{AgP}$ composite coatings was studied by forming $\mathrm{Zn} / \mathrm{AgP}$ composite coatings on AISI 1018 steel plates using $\mathrm{S}_{0}$ solutions with different concentrations of $\operatorname{AgP}\left(\mathrm{S}_{0}+x \mathrm{~g} \cdot \mathrm{L}^{-1} \mathrm{AgP}(x=0,0.5,1.5,2.5,3.5\right.$ and 4.5$\left.)\right)$. The $\mathrm{Zn} / \mathrm{AgP}$ composite coatings were formed by applying a current density of $8.5 \mathrm{~mA} \cdot \mathrm{cm}^{-2}$ for $60 \mathrm{~min}$ at $25^{\circ} \mathrm{C}$. The morphological characteristics of the coatings were analyzed by SEM-EDX and AFM and are shown in Figure 1. The SEM images show that the morphology of the coatings depends on the concentration of AgP in the solution. In the absence of $\operatorname{AgP}$ (solution $S_{0}$ ) (Figure 1a) the obtained coatings were compact, smooth, with a roughness factor, Ra, of $0.65 \mathrm{~mm}$; some micropores are observed on the surface (see inset of Figure 1a), due to the simultaneous formation of $\mathrm{H}_{2}$ bubbles by the simultaneous reduction of water during zinc deposition. By increasing the concentration of $\mathrm{AgP}$ in the electrolytic solution in the range of 0.5 to $2.5 \mathrm{~g} \cdot \mathrm{L}^{-1}$ (Figure $1 \mathrm{~b}-\mathrm{d}$ ), the $\mathrm{Zn} / \mathrm{AgP}$ composite coatings that forms are more compact and formed of semi-spherical clusters (see insets of Figure $1 \mathrm{~b}-\mathrm{d}$ ), with a significant decrease in the number of pores. This result is attributed to the partial inhibition of $\mathrm{H}_{2}$ evolution by the blocking effect of some active sites by the adsorption of AgP; in addition, the roughness of the coatings increased from 0.69 to $0.81 \mu \mathrm{m}$, respectively. An important change in the morphology of the coatings was observed when the coatings were obtained from electrolytic solutions with concentrations of $\mathrm{AgP}$ greater than $2.5 \mathrm{~g} \cdot \mathrm{L}^{-1}$. $\mathrm{Zn} / \mathrm{AgP}$ composite coatings obtained from electrolytic solutions with AgP concentrations between 3.5 and $4.5 \mathrm{~g} \cdot \mathrm{L}^{-1}$ (Figure 1e,f) were smooth, with crystals oriented perpendicularly to the substrate surface, resulting in the formation of a needle-like surface morphology (see Figure S1, additional information). This morphology was similar to that obtained when polyethoxylated compounds were used as surfactant additives, e.g., PEG 8000 [33] and PEG 20,000 [34,35], for the formation of metal electrodeposits, this result confirms the action of the $\mathrm{AgP}$ on the substrate surface. The roughness measured in these coatings was 0.84 and $1.12 \mu \mathrm{m}$, respectively.
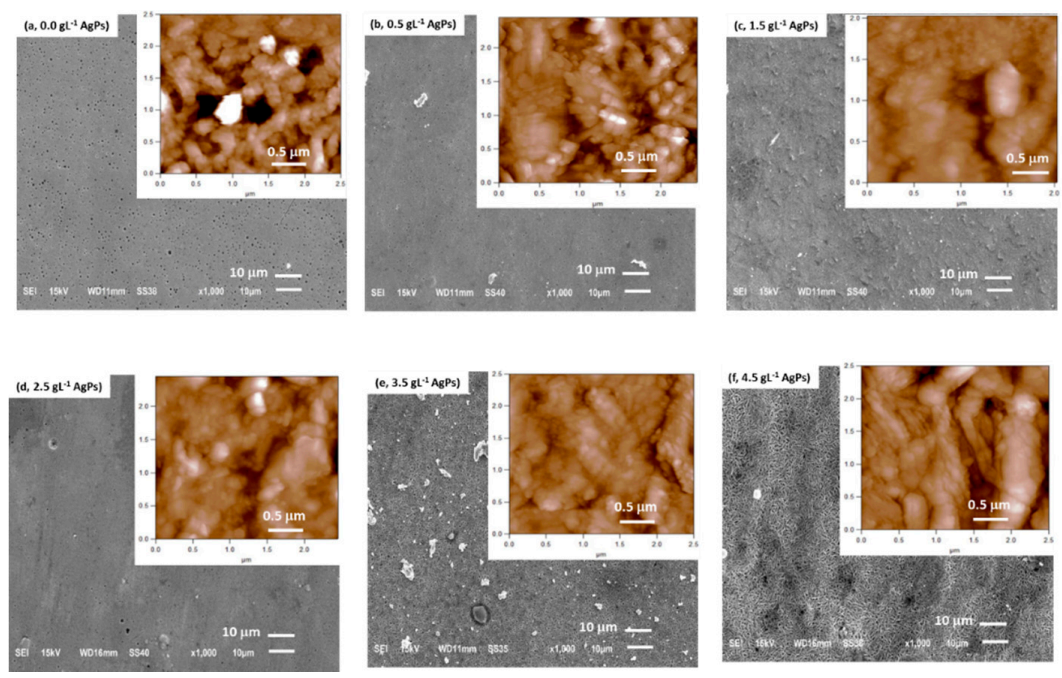

Figure 1. SEM and AFM (insets) images of $\mathrm{Zn} / \mathrm{AgP}$ composite coatings obtained from different electrolytes: (a) $\mathrm{S}_{0}\left(=81 \mathrm{~g} \cdot \mathrm{L}^{-1} \mathrm{ZnCl}_{2}+25 \mathrm{~g} \cdot \mathrm{L}^{-1} \mathrm{H}_{3} \mathrm{BO}_{3},+208.8 \mathrm{~g} \cdot \mathrm{L}^{-1} \mathrm{KCl}+1.5 \mathrm{~g} \cdot \mathrm{L}^{-1} \mathrm{PEG} 8000\right.$ $+0.2 \mathrm{~g} \cdot \mathrm{L}^{-1} \mathrm{BDA}+0.03 \mathrm{~g} \cdot \mathrm{L}^{-1}$ cetyl trimethylammonium hydrogen sulphate (CTHS) $+2.8 \mathrm{~g} \cdot \mathrm{L}^{-1}$ triethanolamine), (b) $S_{0}+0.5 \mathrm{~g} \cdot \mathrm{L}^{-1} \mathrm{AgP},(\mathbf{c}) S_{0}+1.5 \mathrm{~g} \cdot \mathrm{L}^{-1} \mathrm{AgP},\left(\right.$ d) $S_{0}+\mathrm{g} \cdot \mathrm{L}^{-1} \mathrm{AgP},(\mathbf{e}) \mathrm{S}_{0}+3.5 \mathrm{~g} \cdot \mathrm{L}^{-1}$ $\mathrm{AgP},(\mathbf{f}) S_{0}+4.5 \mathrm{~g} \cdot \mathrm{L}^{-1} \mathrm{AgP}$. 
The elemental mapping analysis obtained from the surface of the $\mathrm{Zn} / \mathrm{AgP}$ composite coatings presented in Figure 1d is shown in Figure 2. The EDX surface analysis of the coating detected the presence of $\mathrm{Zn}, \mathrm{O}$ and $\mathrm{Ag}$ homogenously distributed on the surface. This detection confirmed the formation of the $\mathrm{Zn} / \mathrm{AgP}$ composite coating, as well as the surface oxides associated with the reaction of the coating with the air. Similar results were obtained for all coatings (Figure S2, additional information).
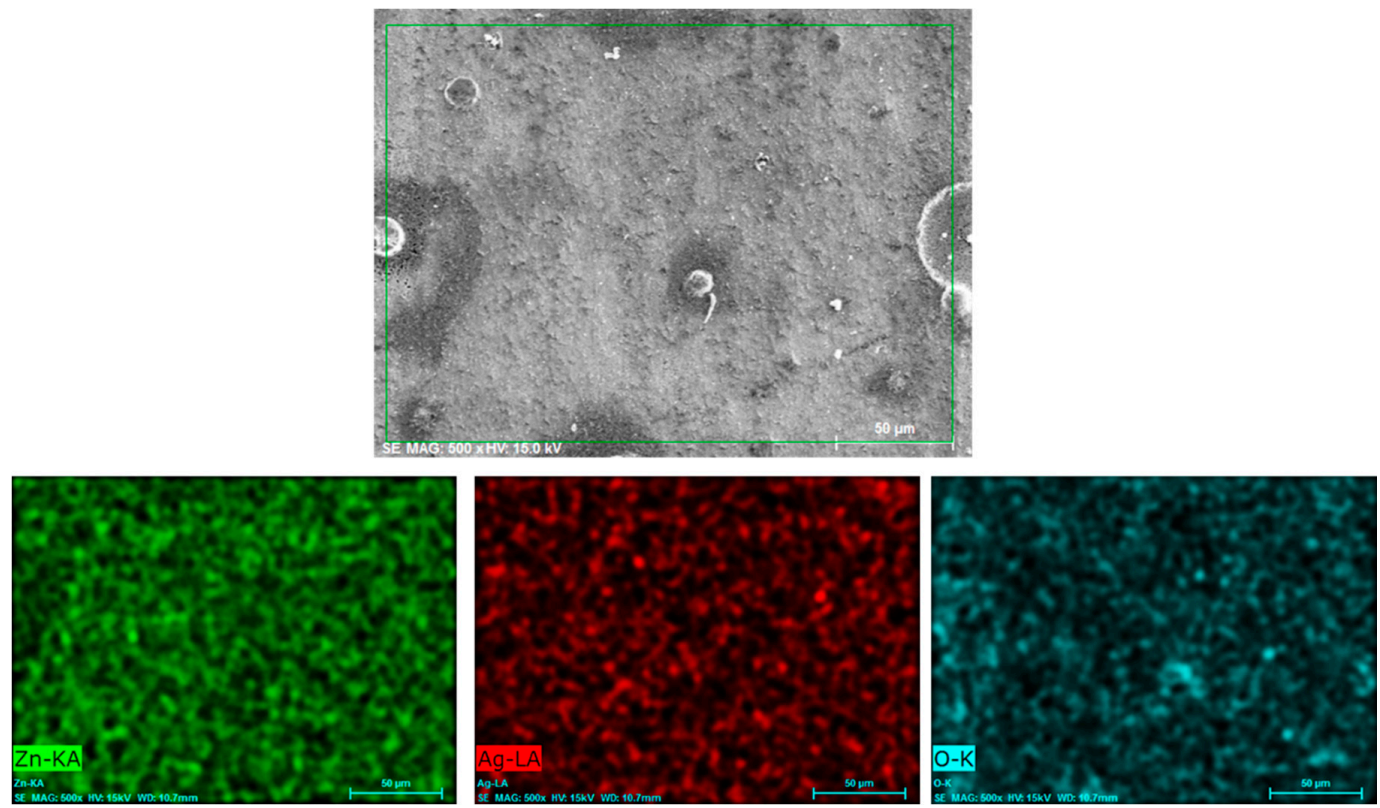

Figure 2. Elemental mapping analyses of the $\mathrm{Zn} / \mathrm{AgP}$ coatings shown in Figure $1 \mathrm{~d}$.

Table 2 shows the results obtained by EDX of the content of Ag on the surface (wt.\% $\mathrm{Ag}_{\text {surf }}$ ) of the $\mathrm{Zn} / \mathrm{AgP}$ coatings formed from solutions with different concentrations of AgP. The surface Ag content (wt.\% $\mathrm{Ag}_{\text {surf }}$ ) increased with the concentration of $\mathrm{AgP}$ in the electrolytic solution, reaching a maximum of $0.30 \mathrm{wt} . \% \mathrm{Ag}\left(0.30 \mathrm{wt} . \% \mathrm{Ag}_{\text {surf }}\right)$ when the concentration of $\mathrm{AgP}$ in the solution was equal to $4.5 \mathrm{~g} \cdot \mathrm{L}^{-1}$. In previous studies, we have shown that the occlusion and homogeneous distribution of an inert particle in metal/inert particle composite coatings is favoured by the use of cationic dispersants [36] (e.g., cetyl trimethylammonium hydrogen sulphate (CTHS), used in this work). This effect is associated with the positive surface charge of the surfactant, which, in addition to stabilizing the particles in the colloidal suspension, promotes their migration towards the surface of the cathode (negatively charged electrode).

Table 2. Results obtained by EDX of the content of $\mathrm{Ag}$ on the surface (wt.\% $\mathrm{Ag}_{\text {surf }}$ ) of the $\mathrm{Zn} / \mathrm{AgP}$ coatings formed from solutions with different concentrations of AgP.

\begin{tabular}{cc}
\hline AgP Concentration in the Electrollytic Solution/ $\mathbf{g ~ L}^{-\mathbf{1}}$ & $\mathbf{w t .} \% \mathbf{A g}$ Surface Composition $\left(\mathbf{w t .} \% \mathbf{A g}_{\text {surf }} \mathbf{)}\right.$ \\
\hline 0 & 0 \\
0.5 & $0.03 \pm 0.01$ \\
1.5 & $0.10 \pm 0.04$ \\
2.5 & $0.18 \pm 0.03$ \\
3.5 & $0.24 \pm 0.02$ \\
4.5 & $0.30 \pm 0.03$ \\
\hline
\end{tabular}

GD-OES analysis was performed to obtain information on the composition and distribution of the elements through the thickness of the $\mathrm{Zn} / \mathrm{AgP}$ composite coatings formed under different conditions. Figure 3 shows the typical profile of the distribution of the elements as a function of the thickness of a $\mathrm{Zn} / \mathrm{AgP}$ composite coating. For clarity, the $\mathrm{H}$ and Ag signals were multiplied by 250. Four regions can 
be observed in the figure. In the first region, in the depth range from 0 to $0.5 \mu \mathrm{m}$, which corresponds to the surface of the coating, the presence of $\mathrm{O}$ and $\mathrm{Zn}$ is observed. The presence of oxygen on the surface of the coating is indicative of the formation of a surface oxide film. Additionally, a high percentage of $\mathrm{Ag}$ is observed and can be associated mainly with an excess of Ag that adhered to the surface after the electrodeposition process and that was not eliminated during the subsequent rinse. After removing the surface oxide film, the second region is observed in the depth range of 0.5 to $7.5 \mu \mathrm{m}$, corresponding to the $\mathrm{Zn} / \mathrm{AgP}$ composite coating. In this region, $\mathrm{Zn}(\sim 99 \%), \mathrm{Ag}(\sim 0.03 \%)$ and $\mathrm{H}(\sim 0.02 \%)$ signals are observed and exhibit a similar and constant behaviour throughout the region; this outcome is indicative of a uniform distribution of these elements throughout the thickness of the coating, as well as the simultaneous co-deposition of $\mathrm{Zn}$ and AgP to form the $\mathrm{Zn} / \mathrm{AgP}$ composite coatings. Subsequently, in the approximate range of 7.5 to $11.5 \mu \mathrm{m}$ (third region), the growth of the Fe signal (substrate) is observed, as well as the simultaneous decrease of the $\mathrm{Zn}$ and Ag signals, indicative of the formation of an interface between the substrate and the coating. At depths greater than $11.5 \mu \mathrm{m}$ (fourth region), there is a constant signal of the Fe substrate $(\sim 100 \%)$, indicating that the substrate has been reached. A similar behaviour, but with different signal intensities, was observed for all of the obtained coatings (Figure S3 additional information). Unlike the EDX results, which show only the surface presence of the elements and not their distribution inside the coatings, the results obtained by GD-OES confirm the homogeneous occlusion of AgP throughout the thickness of the coatings and complement the results obtained by EDX.

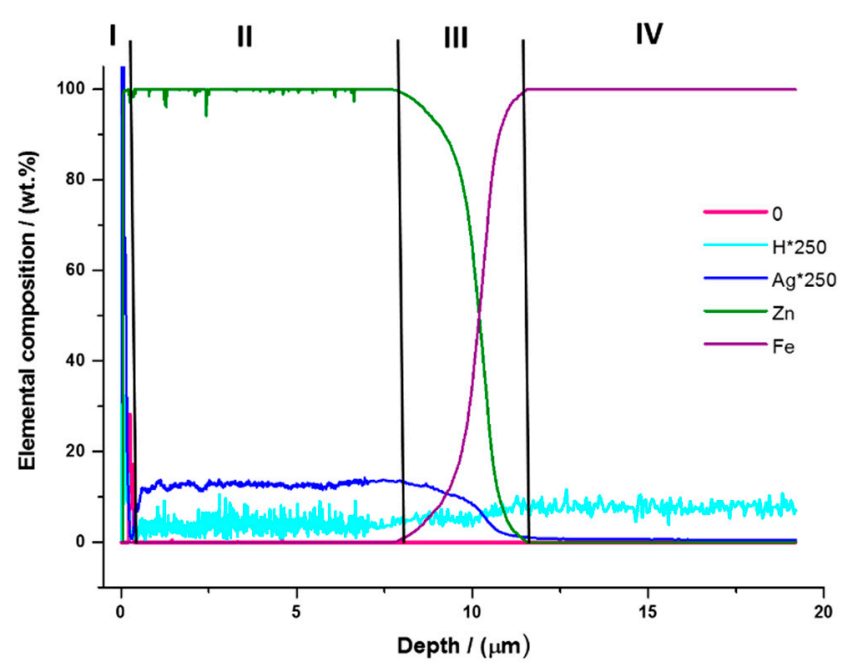

Figure 3. Typical GD-OES profile obtained from a Zn/AgP composite coating formed by applying $8.5 \mathrm{~mA} \mathrm{~cm}{ }^{-2}$ for $60 \mathrm{~min}$ a $25^{\circ} \mathrm{C}$.

\subsection{Antibacterial Activity of the $\mathrm{Zn} / \mathrm{AgP}$ Composite Coatings}

One of the potential applications of $\mathrm{Zn} / \mathrm{AgP}$ composite coatings is their use as a protective coating of implants or prostheses, which is why it is important to evaluate their bactericidal activity with respect to bacteria that cause internal infections. Nosocomial and post-operative infections caused by the Gram-negative bacteria P. aeruginosa are recognized as an acute problem in hospitals due to their intrinsic resistance to many antibiotics $[28,37,38]$. In this work, the antibacterial activity of the $\mathrm{Zn} / \mathrm{AgP}$ composite coatings with different $\mathrm{AgP}$ contents, occluded in their metal matrix, was evaluated against $P$. aeruginosa bacteria during different contact times: 5, 10, 30, 60, and $1440 \mathrm{~min}$, following the methodology described in Section 2.3. The results obtained (Figure 4) show that by increasing the content of $\mathrm{Ag}$ in the $\mathrm{Zn} / \mathrm{AgP}$ composite coatings and the contact time, the bacterial growth decreases considerably. 


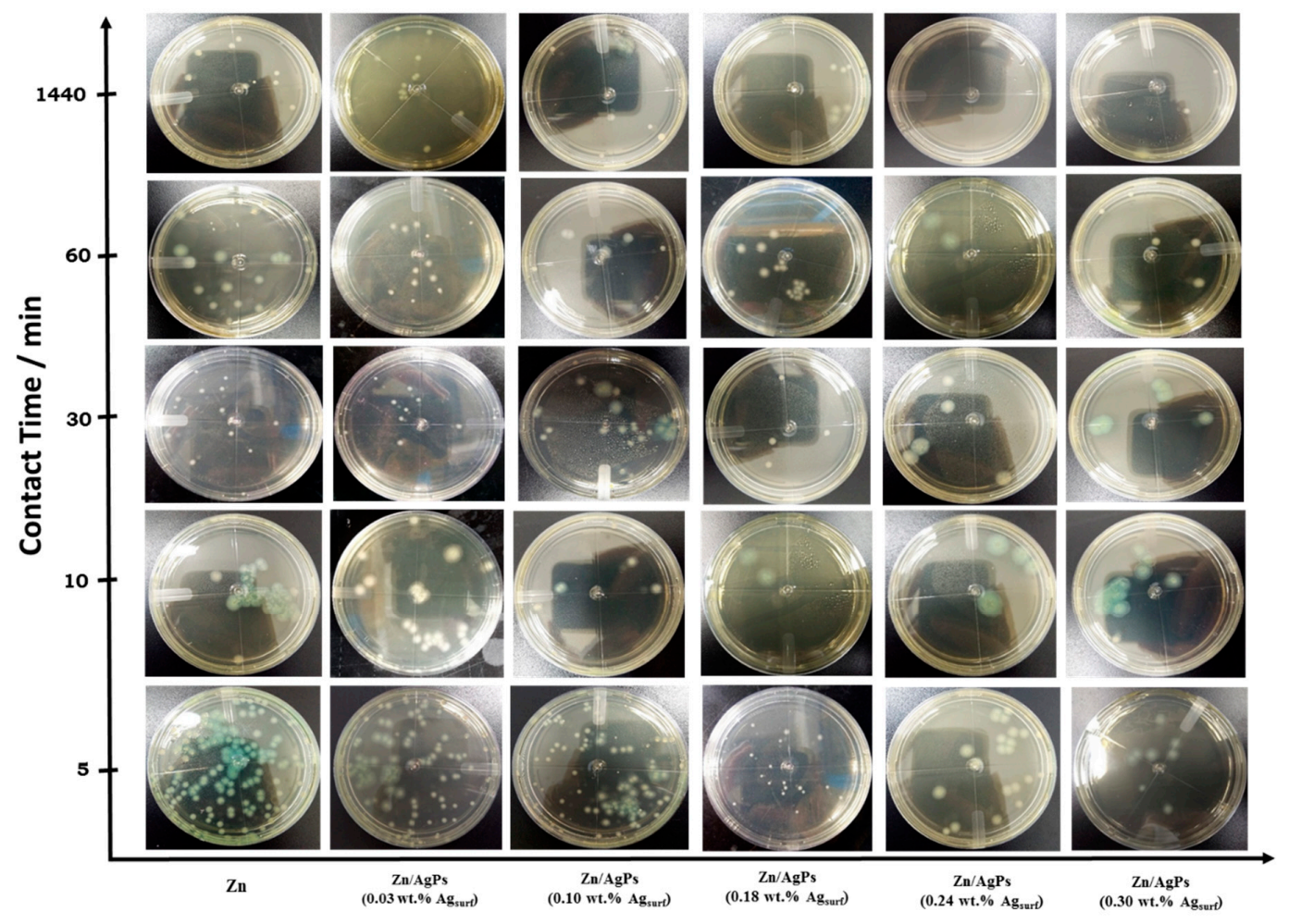

Figure 4. Agar plate assays to assess the antibacterial activity of $\mathrm{Zn} / \mathrm{AgP}$ composite coatings with different contents (wt.\%) of Ag and different contact times with the pathogenic Gram-negative bacterial strain $P$. aeruginosa and $24 \mathrm{~h}$ de incubation.

In Table 3, the results concerning the cell density in CFU mL $\mathrm{m}^{-1}$ units evaluated in each Petri dish, are shown. Results show that by increasing the contact time and the Ag content in the coatings, the cell density decreases. According to these results, the greatest bacterial growth inhibitory effect is observed for $\mathrm{AgP}$ concentrations in the coatings greater than or equal to $0.18 \mathrm{wt} . \% \mathrm{Ag}$ and contact times equal to or greater than $30 \mathrm{~min}$.

Table 3. Final bacterial ( $P$. aeruginosa) concentrations after different contact times between the fermentation broth and $\mathrm{Zn} / \mathrm{AgP}$ surfaces with different $\mathrm{AgP}$ concentrations in the coatings and $24 \mathrm{~h}$ de incubation.

\begin{tabular}{|c|c|c|c|c|c|c|}
\hline \multirow{3}{*}{$\begin{array}{c}\text { Ag Surface } \\
\text { Concentration in } \\
\text { the Coating (wt. } \% \\
\text { Ag }_{\text {surf }} \text { ) }\end{array}$} & \multirow{3}{*}{$\begin{array}{c}\text { Initial } \\
\text { Concentration } P . \\
\text { aeruginosa/CFU } \\
\mathrm{mL}^{-1}\left(\times 10^{9}\right)\end{array}$} & \multicolumn{5}{|c|}{$\begin{array}{l}\text { Final Concentration of Pseudomonas aeruginosa/ } \\
\qquad \text { CFU } \mathrm{mL}^{-1}\left(\times 10^{9}\right)\end{array}$} \\
\hline & & \multicolumn{5}{|c|}{ Contact Time (min) } \\
\hline & & 5 & 10 & 30 & 60 & 1440 \\
\hline 0.0 & 84 & $79.1 \pm 6$ & $74.5 \pm 1$ & $66.5 \pm 13$ & $61.3 \pm 7$ & $53.3 \pm 11$ \\
\hline $0.03 \pm 0.02$ & 88 & $76.0 \pm 8$ & $61.2 \pm 2$ & $57.3 \pm 13$ & $47.7 \pm 13$ & $14.2 \pm 0.7$ \\
\hline $0.10 \pm 0.02$ & 420 & $150.0 \pm 6$ & $112.4 \pm 4$ & $70.2 \pm 1.3$ & $7.6 \pm 1$ & $5.8 \pm 0.2$ \\
\hline $0.18 \pm 0.03$ & 160 & $45.2 \pm 4$ & $29.0 \pm 3$ & $6.7 \pm 2.6$ & $2.3 \pm 0.2$ & $2.1 \pm 0.1$ \\
\hline $0.24 \pm 0.03$ & 110 & $15.5 \pm 1$ & $11.8 \pm 2$ & $3.6 \pm 0.5$ & $2.9 \pm 0.6$ & $1.8 \pm 0.4$ \\
\hline $0.30 \pm 0.02$ & 450 & $60.2 \pm 7$ & $38.6 \pm 3$ & $9.8 \pm 1$ & $11.2 \pm 2$ & $7.7 \pm 1$ \\
\hline
\end{tabular}

The percentage of inhibition of bacterial growth was calculated by quantifying the change in cell density, number of CFU mL ${ }^{-1}$, with respect to the number of initial CFU mL ${ }^{-1}$ present in $10 \mathrm{~mL}$ of a cell suspension after different contact times (5, 10, 30, 60, and $1440 \mathrm{~min}$.) between the Zn/AgP composite coatings and the cell suspension (see Table 3). Each test was performed in triplicate, and the reported result is the average value of these measurements. Figure 5 show that a coating of pure $\mathrm{Zn}$ inhibits the bacterial growth of $P$. aeruginosa up to $36.6 \% \pm 5.1 \%$ after $1440 \mathrm{~min}$ of contact, which confirms the previously reported antibacterial capacity of pure Zn [39]. Likewise, for the Zn/AgP composite 
coatings with $\mathrm{Ag}$ content in the range of $0.18 \mathrm{wt} . \%$ to $0.30 \mathrm{wt} . \%$ Ag surf, percentages of inhibition greater than $90 \%$ were observed after $30 \mathrm{~min}$ of contact, until reaching values close to $100 \%$ inhibition after $60 \mathrm{~min}$ of contact time. The highest percentage of inhibition is observed for $\mathrm{Zn} / \mathrm{AgP}$ with $0.30 \mathrm{wt} . \%$ $\mathrm{Ag}_{\text {surf }}$. Therefore, the $\mathrm{Zn} / \mathrm{AgP}$ composite coatings are highly efficient as antibacterial coatings that can inhibit the growth of bacteria that cause serious internal infections.

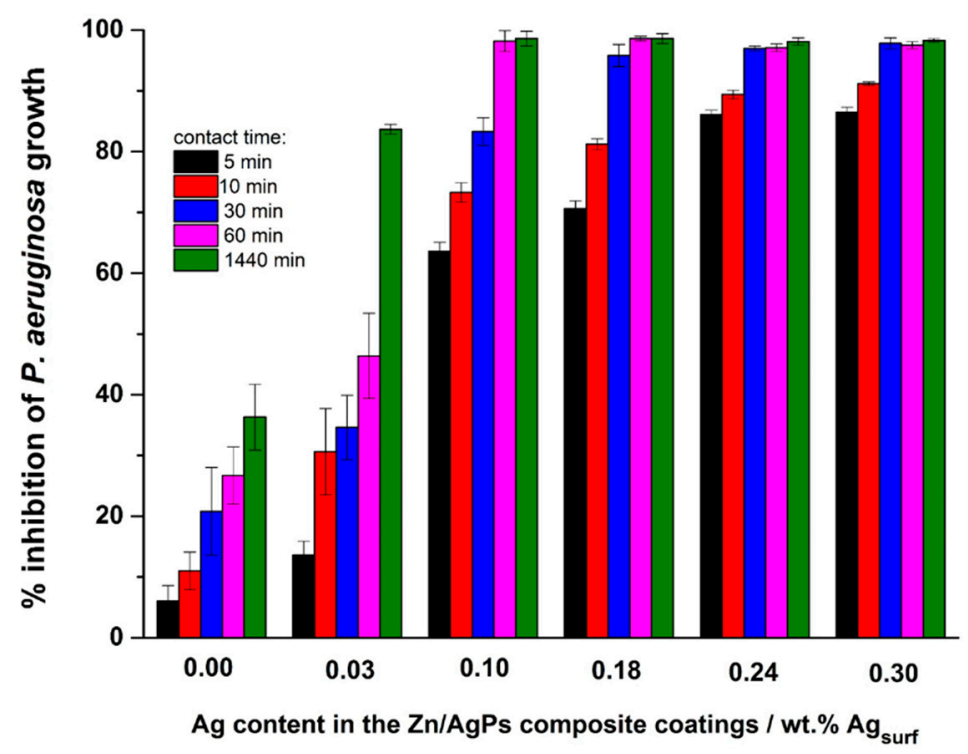

Figure 5. Percentage of inhibition of P. aeruginosa, obtained from counting viable cells in the Petri dish shown in Figure 4.

\subsection{Corrosion Tests}

\subsubsection{Polarization Curves}

To evaluate the corrosion rate of coatings in different physiological environments, polarization curves were obtained for the $\mathrm{Zn} / \mathrm{AgP}\left(0.30 \mathrm{wt} . \% \mathrm{Ag}_{\text {surf }}\right.$ ) composite coatings and the $\mathrm{Zn}$ coating (this coating as reference) immersed in solutions that simulate a physiological environment. The physiological environments selected, Hank's solution [16,40], Ringer's solution [41] and phosphate-buffered saline (PBS) [12], are the most commonly used electrolytic models for in vitro biodegradability studies. The corrosion current density $\left(j_{\text {corr }}\right)$ and the corrosion potential $\left(E_{\text {corr }}\right)$ were obtained graphically using the Tafel extrapolation method. The corrosion rate was calculated using the following equation [31]:

$$
C R=3.27 \times 10^{-3} \frac{j_{c o r r} E W}{\rho}
$$

where $\mathrm{CR}$ is the corrosion rate $\left(\mathrm{mm} \mathrm{yr}^{-1}\right), j_{\text {corr }}$ is the corrosion current density $\left(\mu \mathrm{A} \mathrm{cm}{ }^{-2}\right)$, EW is the equivalent weight of $\mathrm{Zn}(\mathrm{EW}=32.5)$, and $\rho$ is the density of $\mathrm{Zn}\left(7.13 \mathrm{~g} \mathrm{~cm}^{-3}\right)$. Due to the low percentage of $\mathrm{Ag}$ in the $\mathrm{Zn} / \mathrm{AgP}\left(0.30 \mathrm{wt} . \% \mathrm{Ag}_{\text {surf }}\right)$ composite coatings, we considered the coating to be pure $\mathrm{Zn}$ for these calculations. The tests were performed in triplicate for each coating in each solution, and the results reported correspond to the average value obtained. Testing was performed $50 \mathrm{~min}$ after immersion in the range of potential -1.350 to $0.0 \mathrm{~V}$ vs. SCE and with a potential sweep rate of $0.167 \mathrm{mV} \mathrm{s}^{-1}$. Figure 6 shows the polarization curves obtained for the $\mathrm{Zn}$ coatings (Figure 6a) and for the $\mathrm{Zn} / \mathrm{AgP}\left(0.30 \mathrm{wt} . \% \mathrm{Ag}_{\text {surf }}\right.$ ) composite coatings (Figure $6 \mathrm{~b}$ ) in the different physiological solutions. In both coatings, the corrosion potential and the corrosion current density depended on the electrolyte. Additionally, the polarization curves obtained for both coatings in PBS showed passivating characteristics in the region anodic, obtaining passivating current values of $389.20 \mu \mathrm{A} \mathrm{cm}^{-2}$ for the $\mathrm{Zn}$ coating and $70.80 \mu \mathrm{A} \mathrm{cm}^{-2}$ for the $\mathrm{Zn} / \mathrm{AgP}$ composite coating. This behaviour was associated with the 
formation of a passivating film, possibly composed of phosphates, oxides and zinc hydroxides adhered to the surface of the electrode. The formation of this film is possible because during the dissolution of the coating, the $\mathrm{Zn}^{2+}$ ions and $\mathrm{PO}_{4}{ }^{2-}$ ions present in the PBS electrolyte can react to form insoluble zinc phosphate compounds, which have dielectric properties, on the surface of the electrode.

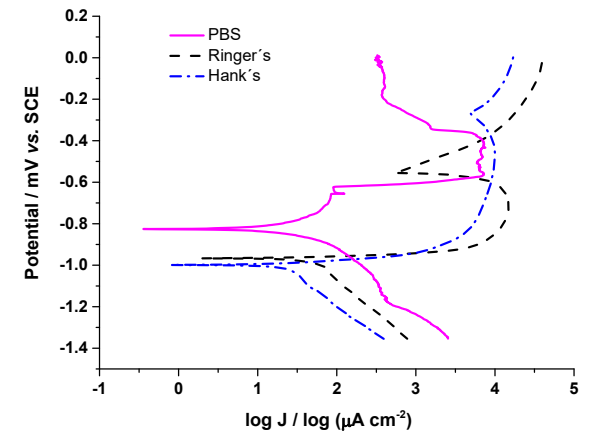

(a)

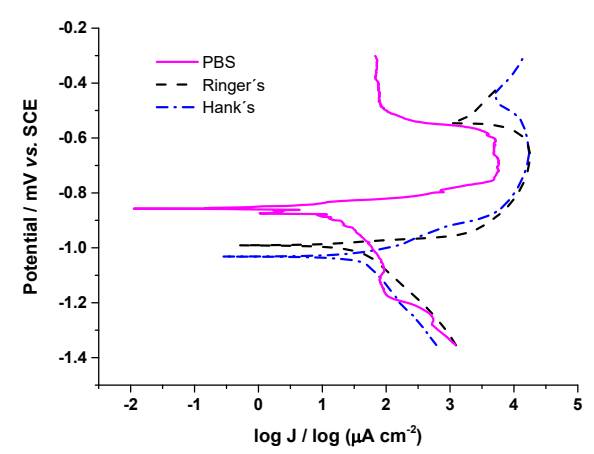

(b)

Figure 6. Polarization curves obtained from (a) Zn coatings and (b) Zn/AgPs (0.30 wt.\% Agsurf) in different physiological solutions.

Table 4 shows the values of $E_{\text {corr }}, J_{\text {corr }}$ and CR obtained from the polarization curves. The highest value of $E_{\text {corr }}$ was obtained for the $\mathrm{Zn}$ and $\mathrm{Zn} / \mathrm{AgP}$ composite coatings immersed in PBS, and this behaviour was similar to that reported by Törne et al. [12] during the study of the degradation of pure $\mathrm{Zn}$ in saline solutions, plasma, and whole blood. Likewise, in all solutions, the $E_{\text {corr }}$ values of the $\mathrm{Zn}$ coating were slightly more noble (higher) than those of the $\mathrm{Zn} / \mathrm{AgP}\left(0.30 \mathrm{wt} . \% \mathrm{Ag}_{\text {surf }}\right.$ ) composite, while the $j_{\text {corr }}$ and $\mathrm{CR}$ values of the $\mathrm{Zn} / \mathrm{AgP}\left(0.30 \mathrm{wt} . \% \mathrm{Ag}_{\text {surf }}\right)$ composite were lower (approximately half, in the case of PBS and Hank's solutions) compared to the pure Zn coatings. Therefore, the presence of $\mathrm{AgPs}$ in the $\mathrm{Zn} / \mathrm{AgP}$ coatings decreased their corrosion rate. This result is consistent with that reported by Punith et al. [42], who studied the corrosion of $\mathrm{Zn} / \mathrm{Ag}$ composites in $\mathrm{NaCl}$ saline solutions and associated the lower corrosion rate of $\mathrm{Zn} / \mathrm{Ag}$ composites with respect to $\mathrm{Zn}$ because the $\mathrm{Ag}$ particles occluded in the coating minimize defects in the coating, which are active sites for corrosion. However, the trend of our results is contrary to those reported by Sikova-Jasenska et al. [18], who found that by increasing the Ag content in $\mathrm{Zn}$-Ag alloys formed by smelting at $650{ }^{\circ} \mathrm{C}$, the values of $\mathrm{j}_{\text {corr }}$ and $\mathrm{CR}$ were slightly increased when using Hank's solution as electrolyte, and those of Törne et al. [17], who reported increases in the corrosion rate of $\mathrm{Zn}-4 \mathrm{Ag}$ alloys $\left(4 \mathrm{wt} . \% \mathrm{Ag}\right.$ ) (formed by smelting at $550{ }^{\circ} \mathrm{C}$ ) with respect to pure $\mathrm{Zn}$. The observed differences can be explained taking into account that in the $\mathrm{Zn}-\mathrm{Ag}$ alloy obtained by heat treatment the formation of intermetallic compounds as $\mathrm{AgZn}_{3}$ of low corrosion resistance is favoured, contrary to what happens with $\mathrm{Zn} / \mathrm{AgP}$ composite electrodeposited coatings in which these types of compounds are not formed.

On the other hand, the values of $j_{\text {corr }}$ were of the same order of magnitude as those reported for the degradation of $\mathrm{Zn}-\mathrm{Mg}$ and $\mathrm{Zn}-\mathrm{Al}$ alloys in Hank's solution [19], as well as of Zn-Ag alloys in Hank's solution [18]. Additionally, the values of $j_{\text {corr }}$ obtained for the $\mathrm{Zn} / \mathrm{AgP}$ composites in the three different electrolytes (PBS, Ringer's and Hank's solutions) were lower than those reported for the degradation of $\mathrm{Mg}$ in Ringer's solution (41.7 $\left.\mu \mathrm{A} \mathrm{cm}^{-2}\right)$ [41] or in simulated body fluid (SBF) $\left(53 \mu \mathrm{A} \mathrm{cm}^{-2}\right)$ [3]. Based on the above results, it is possible to propose $\mathrm{Zn} / \mathrm{AgP}$ composites as a viable alternative to temporarily protect substrates in physiological environments.

Additionally, Table 4 shows the values of the daily amount of dissolved Zn mass $\left(v_{\text {diss }}\right)$ in each of the degradation tests, calculated from the obtained $C R$ values. These values are in the range of $0.1 \mathrm{mg} \mathrm{cm}^{-2}$ day $^{-1}$ to $0.7 \mathrm{mg} \mathrm{cm}^{-2}$ day $^{-1}$, values lower than the necessary daily intake of $\mathrm{Zn}$, which is 8-25 mg day ${ }^{-1}$ for adults and 2 at $8 \mathrm{mg} \mathrm{day}^{-1}$ for children [14,18]. Therefore, from a point of view of biocompatibility, it could be considered that the amount of $\mathrm{Zn}$ dissolved under the conditions studied 
does not present toxicological problems to the organism, provided that the exposed area inside an implant does not lead to concentrations above the permissible range. Additionally, considering the percentage of AgP in the dissolved mass, the amount of Ag mass (approx. $0.24 \mu \mathrm{g} \mathrm{day}^{-1} \mathrm{~cm}^{-2}$ ) is lower than the recommended daily intake $\left(27 \mu \mathrm{g}_{\text {day }}{ }^{-1}\right)$ [43], so it does not represent problems of toxicity either.

Table 4. Corrosion parameters of $\mathrm{Zn}$ coatings and $\mathrm{Zn} / \mathrm{AgP}\left(0.30 \mathrm{wt} . \% \mathrm{Ag}_{\text {surf }}\right)$ composite coatings in different physiological solutions, obtained from the polarization curves.

\begin{tabular}{|c|c|c|c|c|c|}
\hline $\begin{array}{l}\text { Physiological } \\
\text { Solution }\end{array}$ & Coatings & $\begin{array}{c}E_{\text {corr }} \\
(\mathrm{V} \cdot \text { vs SCE })\end{array}$ & $\begin{array}{c}J_{\text {corr }} \\
\left(\mu \mathrm{A} \cdot \mathrm{cm}^{-2}\right)\end{array}$ & 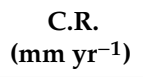 & $\begin{array}{c}V_{\text {diss }} \\
\left(\mathrm{mg} \cdot \mathrm{cm}^{-2} \cdot \mathrm{day}^{-1}\right)\end{array}$ \\
\hline \multirow[b]{2}{*}{ PBS } & $\mathrm{Zn}$ & $-0.827 \pm 0.012$ & $13.06 \pm 2.10$ & $0.19 \pm 0.03$ & $0.37 \pm 0.06$ \\
\hline & $\begin{array}{c}\mathrm{Zn} / \mathrm{AgP} \\
\left(0.30 \text { wt. } \% \mathrm{Ag}_{\text {surf }}\right)\end{array}$ & $-0.848 \pm 0.010$ & $5.18 \pm 0.72$ & $0.08 \pm 0.01$ & $0.15 \pm 0.02$ \\
\hline \multirow{2}{*}{ Ringer's } & $\mathrm{Zn}$ & $-0.966 \pm 0.010$ & $23.02 \pm 2.87$ & $0.34 \pm 0.04$ & $0.66 \pm 0.08$ \\
\hline & $\begin{array}{c}\mathrm{Zn} / \mathrm{AgP} \\
\left(0.30 \text { wt. } \% \mathrm{Ag}_{\text {surf }}\right)\end{array}$ & $-0.985 \pm 0.012$ & $17.77 \pm 2.50$ & $0.26 \pm 0.04$ & $0.50 \pm 0.08$ \\
\hline \multirow[b]{2}{*}{ Hank's } & $\mathrm{Zn}$ & $-1.017 \pm 0.008$ & $18.33 \pm 3.13$ & $0.27 \pm 0.05$ & $0.52 \pm 0.09$ \\
\hline & $\begin{array}{c}\mathrm{Zn} / \mathrm{AgP} \\
\left(0.30 \text { wt. } \% \mathrm{Ag}_{\text {surf }}\right)\end{array}$ & $-1.032 \pm 0.013$ & $10.10 \pm 2.74$ & $0.15 \pm 0.04$ & $0.29 \pm 0.08$ \\
\hline
\end{tabular}

\subsubsection{Immersion Test}

In addition to the study of polarization curves, the corrosion resistance of the $\mathrm{Zn}$ and $\mathrm{Zn} / \mathrm{AgP}$ ( $\left.0.30 \mathrm{wt} . \% \mathrm{Ag}_{\text {surf }}\right)$ coatings was studied by immersion tests, in accordance with NACE Standard TMO $169 / \mathrm{G} 31-12^{\mathrm{a}}$ [32]. For this test, coatings of $\mathrm{Zn}$ and $\mathrm{Zn} / \mathrm{AgP}\left(0.30 \mathrm{wt} . \% \mathrm{Ag}_{\text {surf }}\right)$ were immersed in the three physiological environments considered, while maintaining the temperature at $37^{\circ} \mathrm{C}$. The coatings were removed after different immersion times (7, 22, and 40 days), and their surface was analysed by SEM-EDS to obtain information on the corrosion products.

Figure 7 shows the SEM images obtained from the $\mathrm{Zn}$ (Figure $7 \mathrm{a})$ and $\mathrm{Zn} / \mathrm{AgP}\left(0.30 \mathrm{wt} . \% \mathrm{Ag}_{\text {surf }}\right.$ ) coatings (Figure $7 \mathrm{~b}$ ) after immersion for the different times. In each solution, both coatings had a similar superficial appearance. In PBS, after 7 days of immersion, the presence of crystalline structures was observed on the surface of both coatings. The elemental mapping of the surface (Figure S4a, additional information) shows that these crystals are formed of $\mathrm{P}$ and $\mathrm{O}$, which cover the surface of $\mathrm{Zn}$, forming a protective film. These results corroborate the formation of a passivating film observed in the polarization curves in PBS. The formation of an insoluble phosphate film can be attributed to the presence of hydrogen phosphate in PBS, which reacts with the dissolved $\mathrm{Zn}^{2+}$ ions during the corrosion process and forms insoluble $\mathrm{Zn}$-phosphate species. Additionally, after 40 days of testing, the surface of the sample was completely covered by the protective film. Importantly, at the end of the test, the formation of precipitate in the solution was not observed.

In Hank's solution at seven days of immersion, the formation of a film that partially covered the surface of the coatings was observed. Elemental mapping by EDS showed that this film was composed mainly of Zn and O (Figure S4b, additional information). This result was corroborated by XPS analysis (Figure S5, additional information), whose spectrum presented the characteristic behaviour of $\mathrm{ZnO}$ [44]. After 40 days of immersion, the film partially covered the surface because partial detachment of the film was observed. 

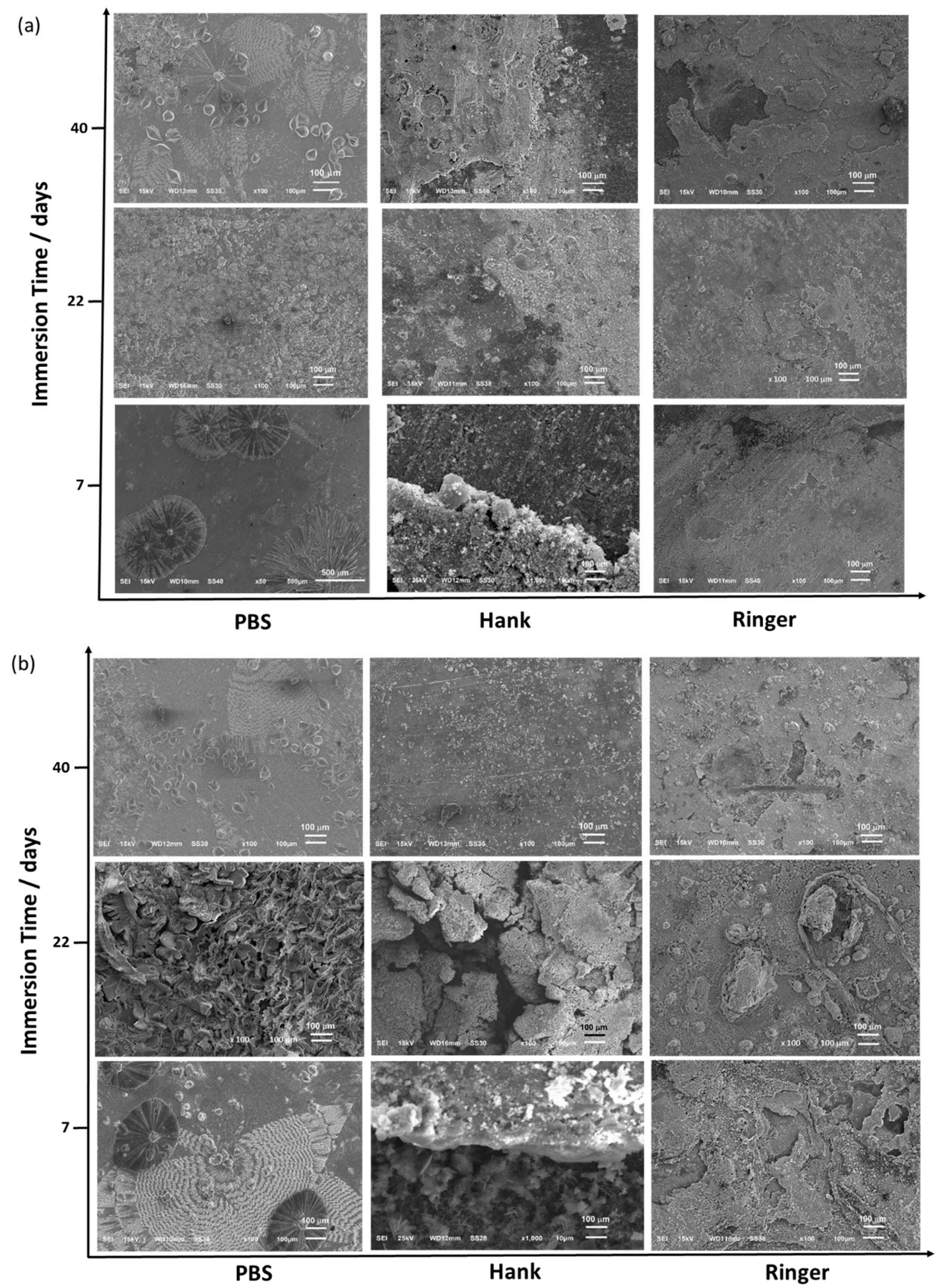

Figure 7. SEM images of $\mathrm{Zn}$ coatings (a) and $\mathrm{Zn} / \mathrm{AgP}(\mathbf{b})(0.30 \mathrm{wt} . \% \mathrm{Ag})$ composite coatings obtained after different immersion times in different physiological solutions at $37^{\circ} \mathrm{C}$.

In Ringer's solution, the coatings showed the formation of a poorly adherent film, and the elemental mapping (Figure S4c, additional information) indicated that this film was primarily formed of $\mathrm{Zn}$ and $\mathrm{O}$. Additionally, after $40 \mathrm{~h}$ of immersion, the presence of Fe was detected, which is indicative of substrate corrosion. 
After 40 days of immersion, the corrosion rate was evaluated using the following equation [26]:

$$
C R=87400 x\left(\frac{W}{A t}\right)
$$

where $\mathrm{CR}$ is the corrosion rate $\left(\mathrm{mm} \mathrm{yr}^{-1}\right), W$ is the weight loss $(\mathrm{g}), \mathrm{A}$ is the area $\left(\mathrm{cm}^{2}\right), t$ is the exposure time (h) and $\rho$ is the density of the material $\left(\mathrm{g} \mathrm{cm}^{3}\right)$. Table 5 shows the results of the corrosion rates obtained for both coatings in the different environments studied. The results were slightly higher than those obtained by the polarization curve technique. However, they followed the same trend.

Table 5. Corrosion rate (CR) of $\mathrm{Zn}$ coatings and $\mathrm{Zn} / \mathrm{AgP}\left(0.30 \mathrm{wt} . \% \mathrm{Ag}_{\text {surf }}\right.$ ) composite coatings after immersion in different physiological solutions for 40 days at $37^{\circ} \mathrm{C}$.

\begin{tabular}{|c|c|c|c|}
\hline Physiological Solution & Coatings & $\begin{array}{c}\text { C.R. } \\
\left(\mathrm{mm} \mathrm{y}^{-1}\right)\end{array}$ & $\begin{array}{c}V_{\text {diss }} \\
\left(\mathrm{mg} \mathrm{cm}^{-2} \text { day }^{-1}\right)\end{array}$ \\
\hline \multirow[b]{2}{*}{ PBS } & $\mathrm{Zn}$ & $0.10 \pm 0.033$ & $0.19 \pm 0.06$ \\
\hline & $\begin{array}{c}\mathrm{Zn} / \mathrm{AgPs} \\
\left(0.30 \text { wt.\% } \mathrm{Ag}_{\text {surf }}\right)\end{array}$ & $0.06 \pm 0.02$ & $0.12 \pm 0.03$ \\
\hline \multirow[b]{2}{*}{ Ringer } & $\mathrm{Zn}$ & $1.07 \pm 0.29$ & $2.09 \pm 0.58$ \\
\hline & $\begin{array}{c}\mathrm{Zn} / \mathrm{AgPs} \\
\left(0.30 \text { wt.\% } \mathrm{Ag}_{\text {surf }}\right)\end{array}$ & $0.88 \pm 0.18$ & $1.72 \pm 0.35$ \\
\hline \multirow[b]{2}{*}{ Hanks } & $\mathrm{Zn}$ & $0.55 \pm 0.18$ & $1.07 \pm 0.34$ \\
\hline & $\begin{array}{c}\mathrm{Zn} / \mathrm{AgPs} \\
\left(0.30 \text { wt. } \% \mathrm{Ag}_{\text {surf }}\right)\end{array}$ & $0.41 \pm 0.12$ & $0.80 \pm 0.23$ \\
\hline
\end{tabular}

\subsection{Characterization of Corrosion Products}

Surface analysis by XRD was performed to identify the corrosion products formed after immersing the coatings for 40 days in the different electrolytes (Figure 8). These results confirmed the formation of zinc oxide $(\mathrm{ZnO})$ on the surface of the $\mathrm{Zn}$ and $\mathrm{Zn} / \mathrm{AgP}\left(0.30 \mathrm{wt} . \% \mathrm{Ag}_{\text {surf }}\right)$ coatings after being immersed in Hank's solution for 40 days at $37^{\circ} \mathrm{C}$ (Figure 8a). Likewise, the presence of the Fe signal corroborated the corrosion of the substrate. Notably, although the compound $\mathrm{NaHPO}_{4}$ is present in Hank's solution, the XRD analysis did not detect the formation of insoluble species of zinc phosphate on the coating surfaces, most likely due to the presence of chloride ions in the solution, which inhibits the formation of zinc phosphates and promotes the formation of soluble species.

A similar behaviour was observed in the XRD diffractograms obtained from the $\mathrm{Zn}$ and $\mathrm{Zn} / \mathrm{AgP}$ (0.30 wt.\% Ag $\mathrm{Agurf}_{\text {s }}$ ) coatings immersed in Ringer's solution (Figure $8 \mathrm{~b}$ ). However, in addition to the $\mathrm{ZnO}$ and $\mathrm{Fe}$ signals, signals associated with $\mathrm{ZnCO}_{3}$ were observed due to the interaction of $\mathrm{Zn}^{2+}$ ions (dissolved during corrosion) and $\mathrm{CO}_{3}{ }^{2-}$ ions that are present in Ringer's solution under alkaline conditions.

The XRD diffractograms obtained from the $\mathrm{Zn}$ and $\mathrm{Zn} / \mathrm{AgP}\left(0.30 \mathrm{wt} . \% \mathrm{Ag}_{\text {surf }}\right)$ coatings immersed for 40 days in PBS at $37^{\circ} \mathrm{C}$ (Figure 8c) showed the presence of signals associated with $\mathrm{Zn}_{3}\left(\mathrm{PO}_{4}\right)_{2} \cdot 2 \mathrm{H}_{2} \mathrm{O}$, which in the absence of chloride ions forms a passivating film on the surface of the coatings. Additionally, the formation of $\mathrm{KH}_{2} \mathrm{PO}_{4}$ and $\mathrm{ZnO}$ was observed. 
(a) $\quad \mathrm{ZnO} \cdot \mathrm{Fe}$

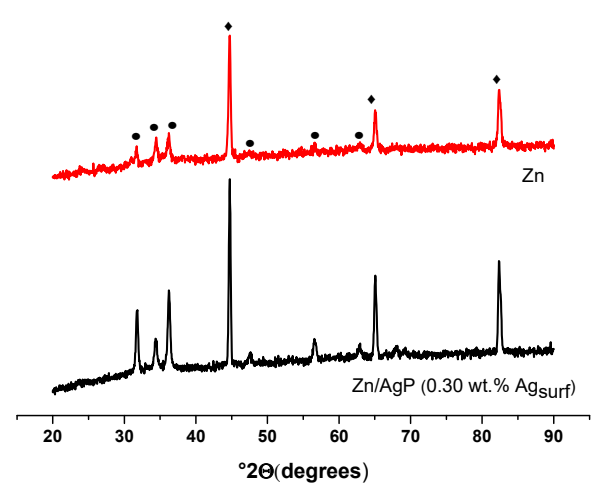

(b) $\quad \mathrm{ZnO} \diamond \mathrm{ZnCO}_{3} \cdot \mathrm{Fe}$
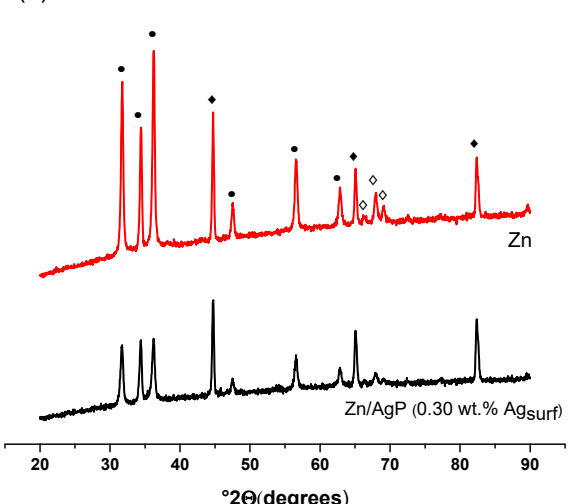

(c) $\quad \Delta \mathrm{Zn}_{3}\left(\mathrm{PO}_{4}\right)_{2} \cdot 2 \mathrm{H}_{2} \mathrm{O} \cdot \mathrm{ZnO} \diamond \mathrm{Zn} \cdot \mathrm{KH}_{2} \mathrm{PO}_{4}$

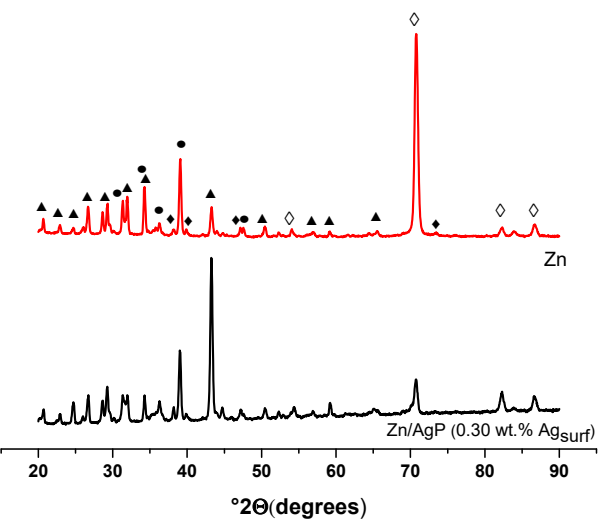

Figure 8. Normalized XRD patterns of $\mathrm{Zn}$ coatings and $\mathrm{Zn} / \mathrm{AgP}(0.30 \mathrm{wt}$. $\% \mathrm{Ag})$ composite coatings obtained after 40 days of immersion at $37^{\circ} \mathrm{C}$ in (a) Hank's solution, (b) Ringer's solution and (c) PBS. Zn (JCPDS 04-0831), ZnO (JCPDS 36-1451), $\mathrm{Zn}_{3}\left(\mathrm{PO}_{4}\right)_{2} \cdot 2 \mathrm{H}_{2} \mathrm{O}$ (JCPDS 041-0493), $\mathrm{ZnCO}_{3}$ (JCPDS 08-0449), $\mathrm{Fe}$ (JCPDS 06-0696), $\mathrm{KH}_{2}\left(\mathrm{PO}_{4}\right)$ (JCPDS 01-527).

\section{Conclusions}

In this study, $\mathrm{Zn} / \mathrm{AgP}$ composite coatings were formed by electrodeposition. The antibacterial properties of the coatings were evaluated using P. aeruginosa NEJ01R as a model Gram-negative bacteria. Likewise, the degradation rate of these coatings in physiological environments was evaluated by means of polarization curve assessment and immersion tests using PBS, Hank's and Ringer's solutions as electrolytes.

$\mathrm{Zn} / \mathrm{AgP}$ composite coatings with different contents of occluded Ag that was homogenously distributed in the metallic matrix were obtained by varying the concentration of AgPs in the electrolytic solution. The antibacterial capacity of the $\mathrm{Zn} / \mathrm{AgP}$ composite coatings depended on the Ag content in the coating and on the contact time. Percentages close to 100\% inhibition were obtained after $30 \mathrm{~min}$ of contact for $\mathrm{Zn} / \mathrm{AgP}$ composite coatings with $\mathrm{AgP}$ content in the range between 0.18 and $0.30 \mathrm{wt} . \%$.

The values of the corrosion current density ( $\left.\mathrm{j}_{\text {corr }}\right)$ of the $\mathrm{Zn} / \mathrm{AgP}$ coatings $\left(0.30 \mathrm{wt} . \% \mathrm{Ag}_{\text {surf }}\right)$ evaluated in PBS, Hank's and Ringer's solutions were 5.18, 17.77 and $10.10 \mu \mathrm{A} \mathrm{cm}^{-2}$, respectively, which are similar to those normally considered for the design of biodegradable materials, such as $\mathrm{Zn}-\mathrm{Mg}$ and $\mathrm{Zn}-\mathrm{Al}$, and lower than those reported for $\mathrm{Mg}\left(\sim 50 \mu \mathrm{A} \mathrm{cm}{ }^{-2}\right)$. Additionally, the amount of dissolved mass of the $\mathrm{Zn} / \mathrm{AgP}$ coatings in the physiological environments considered (PBS, Hank's and Ringer's solutions) were $0.15,0.29$, and $0.15 \mathrm{mg} \mathrm{cm}^{-2}$ day $^{-1}$, respectively, which are much lower than the recommended daily $\mathrm{Zn}$ intake (15-100 $\mathrm{mg}$ day $^{-1}$ ).

The XRD analysis confirmed the formation of $\mathrm{ZnO}$ species on the surface of the coatings immersed in Ringer's and Hank's solutions, while the coatings immersed in PBS showed the formation of an 
adherent film of $\mathrm{Zn}_{3}\left(\mathrm{PO}_{4}\right)_{2} \cdot 2 \mathrm{H}_{2} \mathrm{O}$. This protective film is formed by the reaction between the $\mathrm{Zn}^{2+}$ ions produced by the dissolution of the $\mathrm{Zn}$ film and the $\mathrm{PO}_{4}{ }^{2-}$ anions present in the solution. This reaction did not occur in coatings immersed in Hank's solution, which does contain $\mathrm{PO}_{4}{ }^{2-}$ ions, because it also contains chloride ions that can easily form soluble chloride species.

Based on the results obtained, it is possible to propose $\mathrm{Zn} / \mathrm{AgP}$ composites coatings as an alternative for use as temporary biodegradable protective coatings of implants with the capacity to inhibit the formation of bacterial biofilms on their surface.

Supplementary Materials: The following are available online at http://www.mdpi.com/2079-6412/10/4/337/s1, Figure S1 SEM images of $\mathrm{Zn} / \mathrm{AgP}$ composite coatings obtained from S0 solution $\left(=81 \mathrm{~g} \cdot \mathrm{L}^{-1} \mathrm{ZnCl} 2+25 \mathrm{~g} \cdot \mathrm{L}^{-1}\right.$ $\mathrm{H} 3 \mathrm{BO} 3+208.8 \mathrm{~g} \cdot \mathrm{L}-1 \mathrm{KCl}+1.5 \mathrm{~g} \cdot \mathrm{L}-1$ PEG $8000+0.2 \mathrm{~g} \cdot \mathrm{L}-1 \mathrm{BDA}+0.03 \mathrm{~g} \cdot \mathrm{L}^{-1}$ cetyl trimethylammonium hydrogen sulphate (CTHS) $+2.8 \mathrm{~g} \cdot \mathrm{L}^{-1}$ triethanolamine) $+3.5 \mathrm{~g} \cdot \mathrm{L}^{-1}$ AgNPs. Figure S2 Elemental mapping analyses of the $\mathrm{Zn} / \mathrm{AgP}$ coatings obtained from. (a) $\mathrm{S} 0$ solution $+0.5 \mathrm{~g} \cdot \mathrm{L}^{-1} \mathrm{AgPs}$ (b) $\mathrm{S} 0$ solution $+1.5 \mathrm{~g} \cdot \mathrm{L}^{-1} \mathrm{AgPs}$. (c) $\mathrm{S} 0$ solution + $3.5 \mathrm{~g} \cdot \mathrm{L}^{-1}$ AgPs. (d) S0 solution $+4.5 \mathrm{~g} \cdot \mathrm{L}^{-1}$ AgPs. Figure S3. GD-OES profiles obtained from Zn/AgP composite coatings formed from. S0 solution with: (a) $1.0 \mathrm{~g} \cdot \mathrm{L}^{-1} \mathrm{AgPs}$, (b) $2.5 \mathrm{~g} \cdot \mathrm{L}^{-1} \mathrm{AgPs}$ and (c) $3.5 \mathrm{~g} \cdot \mathrm{L}^{-1} \mathrm{AgPs}$ by applying $8.5 \mathrm{~mA} \mathrm{~cm}^{-2}$ for $60 \mathrm{~min}$ a $25^{\circ} \mathrm{C}$. Figure S4. (a) Elemental mapping analyses of the $\mathrm{Zn}$ and $\mathrm{Zn} / \mathrm{AgP}(0.30 \mathrm{wt} . \% \mathrm{Ag})$ coatings obtained after 7 days of immersion in PBS's solutions at $37^{\circ} \mathrm{C}$. (b) Elemental mapping analyses of the Zn coatings obtained after 7 days of immersion in Hank's solutions at $37^{\circ} \mathrm{C}$. (c) Elemental mapping analyses of the $\mathrm{Zn} / \mathrm{AgP}(0.30 \mathrm{wt} . \% \mathrm{Ag})$ coatings obtained after 7 days of immersion in Ringer's solutions at $37^{\circ} \mathrm{C}$. Figure S5. XPS analyses of the $\mathrm{Zn}$ and $\mathrm{Zn} / \mathrm{AgP}(0.30 \mathrm{wt} . \% \mathrm{Ag})$ coatings obtained after 7 days of immersion in Hank's solutions at $37^{\circ} \mathrm{C}$.

Author Contributions: Methodology, Y.R.-V. and F.J.B.-V.; validation, R.H.L., E.A.-S. and J.V.-A.; formal analysis, J.G.F.; investigation, B.C.-R. and J.M.; writing—original draft preparation, G.T.; writing—review and editing, G.T. and R.O.; project administration, A.T.-L.; funding acquisition, A.T.-L. All authors have read and agreed to the published version of the manuscript.

Funding: This research was funded by Consejo Nacional de Ciencia y Tecnología (CONACyT), México [project CF/2019-6691].

Acknowledgments: Berenice Castro Rodriguez is grateful to CONACyT for scholarship support.

Conflicts of Interest: The authors declare no conflict of interest.

\section{References}

1. Cheng, J.; Liu, B.; Wu, Y.H.; Zheng, Y.F. Comparative in vitro study on pure metals (Fe, Mn, Mg. Zn and W) as biodegradable metals. J. Mater. Sci. Technol. 2013, 29, 619-627. [CrossRef]

2. Li, N.; Zheng, Y. Novel Magnesium alloys developed for biomedical applications: A review. J. Mater. Sci. Technol. 2013, 29, 489-502. [CrossRef]

3. Vojtech, D.; Kubásek, J.; Serák, J.; Novák, P. Mechanical and corrosion properties of newly developed biodegradable Zn-based alloys for bone fixation. Acta Biomater. 2011, 7, 3515-3522. [CrossRef] [PubMed]

4. Heublein, B.; Rohde, R.; Kaese, V.; Niemeyer, M.; Hartung, W.; Haverich, A. Biocorrosion of magnesium alloys: A new principle in cardiovascular implant technology? Heart 2003, 89, 651-656. [CrossRef] [PubMed]

5. Krause, A.; Von der Höh, N.; Bormann, D.; Krause, C.; Bach, F.W.; Windhagen, H.; Meyer-Lindenberg, A. Degradation behavior and mechanical properties of magnesium implants in rabbit tibiae. J. Mater. Sci. 2010, 45, 624-632. [CrossRef]

6. Zhang, S.; Li, J.A.; Song, Y.; Zhao, C.L.; Zhang, X.; Xie, C.; Zhang, Y.; Tao, H.; He, Y.; Jiang, Y.; et al. In vitro degradation, hemolysis and MC3T3-E1 cell adhesion of biodegradable Mg-Zn alloy. Mater. Sci. Eng. C 2009, 29, 1907-1912. [CrossRef]

7. Sun, Y.; Zhang, B.; Wang, Y.; Geng, L.; Jiao, X. Preparation and characterization of a new biomedical Mg-Zn-Ca alloy. Mater. Des. 2012, 34, 58-64. [CrossRef]

8. Peuster, M.; Hesse, C.; Schloo, T.; Fink, C.; Beerbaum, P. Long-term biocompatibility of a corrodible peripheral iron stent in the porcine descending aorta. Biomaterials 2006, 27, 4955-4962. [CrossRef]

9. Peuster, M.; Wohlsein, P.; Brugmann, M.; Ehlerding, M.; Seidler, K.; Fink, C. A novel approach to temporary stenting: Degradable cardiovascular stents produced from corrodible metal-Results 6-18 months after implantation into New Zealand white rabbits. Heart 2001, 86, 563-569. [CrossRef]

10. Hermawan, H.; Purnama, A.; Dube, D.; Couet, J.; Montovani, D. Fe-Mn alloys for metallic biodegradable stents: Degradation and cell viability studies. Acta Biomater. 2010, 6, 1852-1860. [CrossRef] 
11. Schinhammer, M.; Steiger, P.; Moszner, F.; Löffler, J.F.; Uggowitzer, P.J. Degradation performance of biodegradable Fe-Mn-C (-Pd) alloys. Mater. Sci. Eng. C 2013, 33, 1882-1893. [CrossRef] [PubMed]

12. Törne, K.; Larsson, M.; Norlin, A.; Weissenrieder, J. Degradation of zinc in saline solutions, plasma, and whole blood. J. Biomed. Mater. Res. Part B 2016, 104, 1141-1151. [CrossRef] [PubMed]

13. Bowen, P.K.; Drelich, J.; Goldman, J. Zinc exhibits ideal physiological corrosion behavior for bioadsorbables stents. Adv. Mater. 2013, 25, 2577-2582. [CrossRef]

14. Fosmire, G.J. Zinc toxicity. Am. J. Clin. Nutr. 1990, 51, 225-227. [CrossRef] [PubMed]

15. Tapiro, H.; Tew, K.D. Trace elements in human physiology and pathology: Zinc and metallothioneins. Biomed. Pharmacother. 2003, 57, 399-411. [CrossRef]

16. Niu, J.; Tang, Z.; Huang, H.; Pei, H.J.; Zhang, H.; Yuan, G.; Ding, W. Research on a Zn-Cu alloy as a biodegradable material for potential vascular stents applications. Mater. Sci. Eng. C 2016, 69, 407-413. [CrossRef]

17. Törne, K.B.; Khan, F.A.; Örberg, A.; Weissenrieder, J. Zn-Mg and Zn-Ag degradation mechanism under biologically relevante conditions. Surf. Innov. 2018, 6, 81-82. [CrossRef]

18. Sikora-Jasinska, M.; Mostaed, E.; Mostaed, A.; Beanland, R.; Mantovani, D.; Vedani, M. Fabrication, mechanical properties and in vitro degradation behavior of newly developed $\mathrm{Zn}$-Ag alloys for degradable implants applications. Mater. Sci. Eng. C 2017, 77, 1170-1181. [CrossRef]

19. Mostaed, E.; Sikora-Jasinska, M.; Mostaed, A.; Loffredo, S.; Demir, A.G.; Previtali, B.; Mantovani, D.; Beuland, R.; Vedani, M. Novel Zn-based alloys for biodegradable stent applications: Design, development and in vitro degradation. J. Mech. Behav. Biomed. Mater. 2016, 60, 581-602. [CrossRef]

20. Hehrlein, C.; Schorch, B.; Kress, N.; Arab, A.; Von zur Mühlen, C.; Bode, C. Zn-alloy provides a novel platform for mechanically stable bioresorbable vascular stents. PLoS ONE. 2019, 14, e0209111. [CrossRef]

21. Alabbasi, A.; Liyanaarachchi, S.; Kannan, M.B. Polylactic acid coating on a biode-gradable magnesium alloy: An in vitro degradation study by electrochemical impedance spectroscopy. Thin Solid Films 2012, 520, 6841-6844. [CrossRef]

22. Park, M.; Eun, J.; Chun, L.; Park, G.; Ho, S.; Hyun, L.; Seok, K.; Bin Choy, Y. Polycaprolactone coating with varying thicknesses for controlled corrosion of magnesium. J. Coat. Technol. Res. 2013, 10, 695-706. [CrossRef]

23. Ascencio, M.; Pekguleryuz, M.; Omanovic, S. Corrosion behaviour of polypyrrole-coated WE43 Mg alloy in a modified simulated body fluid solution. Corr. Sci. 2018, 133, 261-275. [CrossRef]

24. Chang, L.; Tian, L.; Liu, W.; Duan, X. Formation of dicalcium phosphate dihydrate on magnesium alloy by micro-arc oxidation coupled with hydrothermal treatment. Corr. Sci. 2013, 72, 118-124. [CrossRef]

25. da Conceição, T.F.; Scharnagl, N.; Dietzel, W.; Kainer, K.U. Controlled degradation of a magnesium alloy in simulated body fluid using hydrofluoric acid treatment followed by polyacrylonitrile coating. Corr. Sci. 2012, 62, 83-89. [CrossRef]

26. Rasouli, M.R.; Restrepo, C.; Maltenfort, M.; Purtill, J.J.; Parvizi, J. Risk factors for surgical site infection following total joint arthroplasty. J. Bone Jt. Surg. Am. 2014, 96, e158. [CrossRef]

27. Hernández, A.; Yagüe, G.; Vázquez, E.G.; Simón, M.; Parrado, L.M.; Canteras, M.; Gómez, J. Infecciones nosocomiales por Pseudomonas aeruginosa multiresistente incluido carbapenémicos: Factores predictivos y pronósticos. Estudio prospectivo 2016-2017. Rev. Esp. Quimioter. 2018, 31, 123-130.

28. Fazzeli, H.; Akbari, R.; Moghim, S.; Narimani, T.; Arabestani, M.R.; Ghoddousi, A.R. Pseudomonas aeruginosa infections in patients, hospital means, and personnel's specimens. J. Res. Med. Sci. 2012, 17, 332-337.

29. ISO 22196. Measurement of antibacterial activity on plastics and other non-porous surfaces. In International Organization for Standardization; ISO: Geneva, Switzerland, 2011.

30. ASTM E2149-13a. Standard Test Method for Determining the Antimicrobial Activity of Antimicrobial Agents Under Dynamic Contact Conditions. In American Society for Testing and Materials; ASTM: West Conshohocken, PA, USA, 2013.

31. ASTM G59-97. Standard Test Method for Conducting Potentiodynamic Polarization Resistance Measurements. In American Society for Testing and Materials; ASTM: West Conshohocken, PA, USA, 2014.

32. NACE TMO169/G31-12a. Standard Guide for laboratory Immersion corrosion testing of metals; NACE: Houston, TE, USA, 2012.

33. Trejo, G.; Ortega, R.; Meas, Y. The effect of polyethylene glicol 8000 additive on the deposition mechanism and morphology of Zn deposits. Plat. Surf. Finish. 2002, 89, 84-87. 
34. Kazimierczak, H.; Morgiel, J.; Swiatek, Z.; Vega, J.M. Effect of Mo addition on corrosion of Zn coatings electrodeposited on Steel. Corr. Sci. 2018, 135, 107-119. [CrossRef]

35. Kazimierczak, H.; Szymkiewics, K.; Gileadi, E.; Eliaz, N. The effect of direct and pulsed current in the presence of surfactants on the electrodeposition of Zn-SiC nanocomposite coatings. Coatings 2019, 9, 93. [CrossRef]

36. Méndez-Albores, A.; González-Arellano, S.G.; Reyes-Vidal, Y.; Torres, J.; Ţălu, Ş.; Cercado, B.; Trejo, G. Electrodeposited chrome/silver nanoparticle (Cr/AgNPs) composite coatings: Characterization and antibacterial activity. J. Alloy. Compd. 2017, 710, 302-311. [CrossRef]

37. Masaadeh, H.A.; Jaran, A.S. Incident of Pseudomonas aeruginosa in post-operative wound infection. Am. J. Infect. Dis. 2009, 5, 1-6. [CrossRef]

38. Ohlin, A.; Mattsson, E.; Mörgelin, M.; Davies, J.R.; Esvensâter, G.; Corvec, S.; Tengvall, P.; Riesbeck, K. Titanium granules pre-treated with hydrogen peroxide inhibit growth of bacteria associated with post-operative infections in spine surgery. Eur. Spine J. 2018, 27, 2463-2468. [CrossRef] [PubMed]

39. Bundy, K.J.; Butler, M.F.; Hochman, R.F. An investigation of the bacteriostatic properties of pure metals. J. Biomed. Mater. Res. 1980, 14, 653-663. [CrossRef] [PubMed]

40. Li, H.F.; Xi, H.; Zheng, Y.F.; Cong, Y.; Zhou, F.Y.; Qiu, K.J.; Wang, X.; Chen, S.H.; Huang, L.; Tian, L.; et al. Development of Biodregradable Zn-1X binary alloys with nutrient alloying elements $\mathrm{Mg}$, Ca and Sr. Sci. Rep. 2015, 5, 10719. [CrossRef]

41. Jamesh, M.; Kumar, S.; Sankara Narayanan, T.S.N. Corrosion behavior of commercially pure Mg and ZM21 Mg alloy in Ringer's solution-Long term evaluation by EIS. Corr. Sci. 2011, 53, 645-654. [CrossRef]

42. Punith Kumar, M.K.; Srivastava, C. Morphological and electrochemical characterization of electrodeposited Zn-Ag nanoparticle composite coatings. Mater. Charact. 2013, 85, 82-91. [CrossRef]

43. Hadrup, N.; Lam, H.R. Oral toxicity of silver ions, silver nanoparticles and coloidal silver, a rewiew. Regul. Toxicol. Pharmacol. 2014, 68, 1-7. [CrossRef]

44. Al-Gaashani, R.; Radiman, S.; Daud, A.R.; Tabet, N.; Al-Douri, Y. XPS and optical studies of different morphologies of $\mathrm{ZnO}$ nanostructures prepared by microwave methods. Ceram. Int. 2013, 39, 2283-2292. [CrossRef]

(C) 2020 by the authors. Licensee MDPI, Basel, Switzerland. This article is an open access article distributed under the terms and conditions of the Creative Commons Attribution (CC BY) license (http://creativecommons.org/licenses/by/4.0/). 